1. ábra. A Tempo G 1200 -as katonai terepjáró

Schmidt László

\title{
A Tempo G 1200-as terepjáró gépkocsi
}

A budai Várban sétáló polgároknak különleges élményben lehetett részük 1938. július 5-én, egy hétköznapon. A Halászbástya lépcsőin egy táboriszürke, magyar próbarendszámmal ellátott, nyitott, a megszokottnál hangosabb, és nagyobb füstöt eregető gépkocsi kapaszkodott fel, majd ugyanott lefelé is bemutatta tudását.

A furcsa gépkocsi története azonban jóval korábban kezdődött. Az első, a „nagy háború” utáni vesztes Német-

\section{2. ábra. A Tempo G 1200-as katonai terepjáró elölnézete}

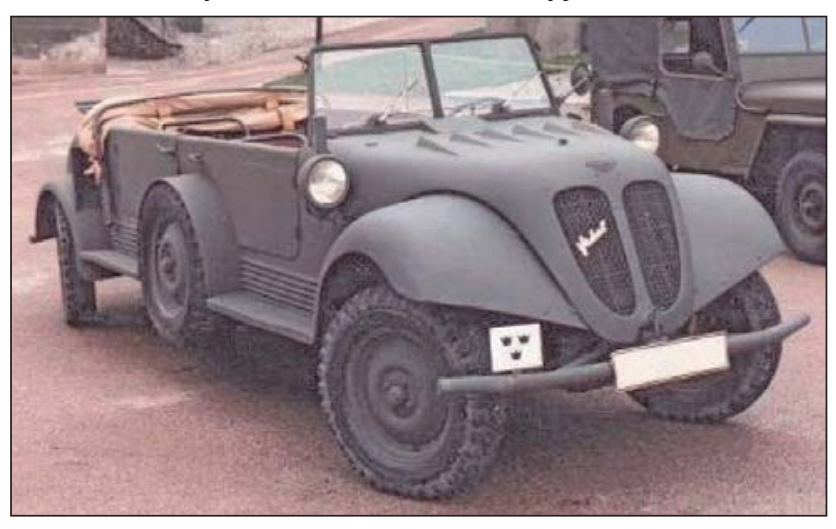

ÖSSZEFOGLALÁS: Az egészen különleges kialakítású, minden addigitól eltérő Tempo G 1200 jármúvet 1936-ban mutatták be. A két motor egyidejü használata összkerékhajtást jelentett, ami a nehéz terepszakaszokon is átsegítette a gépkocsit, valamint külön-külön és együtt is múködtethető volt. Mind a négy kerék kormányozható is volt, valamint az oldalt elhelyezett két pótkerék a tengelyén el tudott forogni, hogy a terepen nem üljön fel a gépkocsi. A típus egyes példányai Magyarországra is eljutottak, a Haditechnikai Intézet is próbáknak vetette alá.

KULCSSZAVAK: katonai terepjáró gépkocsi, Tempo G 1200, Haditechnikai Intézet országban minden szállítóeszköznek nagy értéke volt. Az ezen a téren jelentkező keresletet kielégítendő, 1924-ben az északnémet térségben - így Hamburgban, Brémában egy új iparág kezdett kifejlődni, amely alkalmazkodott az akkori adószabályokhoz. Ennek értelmében a négynél kevesebb kerékkel felszerelt, $200 \mathrm{~cm}^{3}$ motorürtartalom alatti járművek üzemeltetése adómentes volt, és jogosítvány sem kellett a vezetésükhöz.

Az első használható ilyen kis haszonjárművet a brémai Borgward cég készítette. A kocsi sikere sok más vállalkozást is ilyen járművek gyártására ösztönzött. Ezek között volt a hamburgi Tempo-Werk $\mathrm{GmbH}$. Azonnal két típust kínáltak vevőiknek, egy vízhűtéses és egy léghűtéses motorral meghajtott változatot. Ma már furcsán hangzik, de a két típus egyikében sem volt hátramenet. Ez egyszerübbé és olcsóbbá tette a járműveket.

A kedvező piaci fogadtatás ellenére a Tempo cég veszteséges volt, tőkéstársat keresett. A lehetőséggel élve így 1928-ban Max Vidal és fia elhatározták, hogy átveszik a társaságot, és megalapították a Vidal \& Sohn Tempo-Werk $\mathrm{GmbH}$ céget. Vezetésük alatt a vállalkozás nyereségessé vált, mert gyártmányaik a technika akkori szintjén mérve gyors és rendkívül megbízható járművek voltak.

A sikeres kis áruszállító kocsik konstruktőre, a nagyon tehetséges Otto Daus gépészmérnök számtalan új ötletet

ABSTRACT: In 1936, the manufacturer introduced its Tempo G 1200 vehicle of very specific design that differed from all the preceding ones. Simultaneous use of two engine gave all-wheel drive helping the vehicle on rough terrains and they were operable either separately or together. All the four wheel were steerable, and the two side-mounted spare wheels were turnable to avoid taking ground. Some of the vehicles got to Hungary, and the Institute of Military Technology subjected them to tests.

KEY WORDS: military cross-country car, Tempo G 1200, Institute of Military Technology 


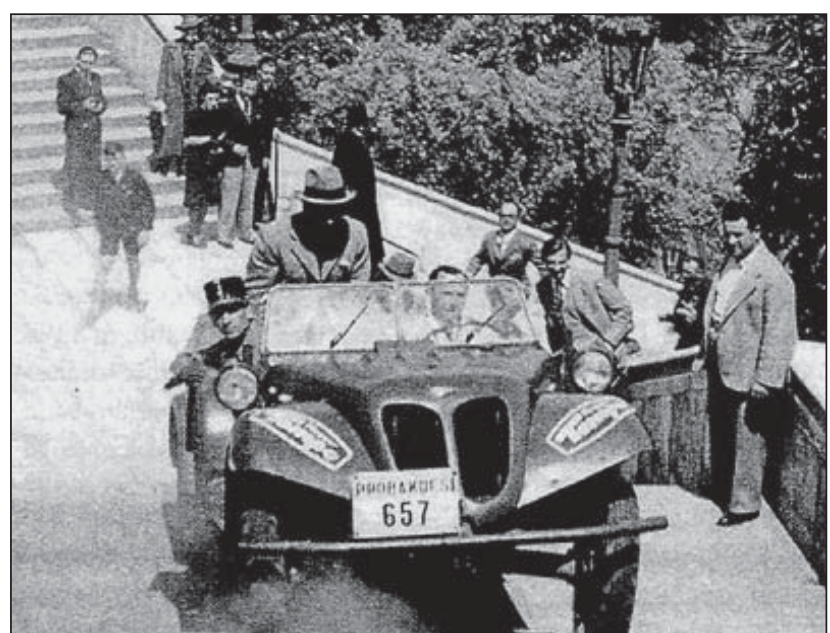

3. ábra. Nagyszerü reklámfogás volt a kocsi terepjáró képességét a Várban, a Halászbástya lépcsőin bemutatni. A benne ülő katonatiszt a Haditechnikai Intézet munkatársa

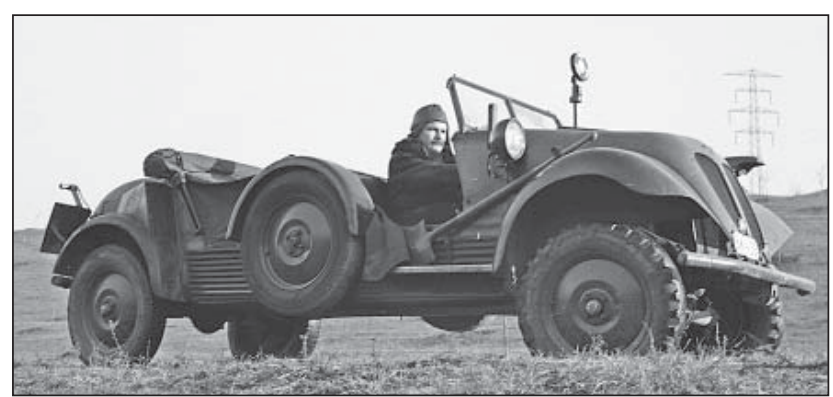

4. ábra. A Tempo G 1200-as katonai terepjáró1943-ban Magyarországon (Fortepan 72628)

alkalmazott a cég gyártmányainál. Álma azonban mindig az volt, hogy egy olyan gépkocsit alkothasson meg, amely mindenhol, messze az épített utaktól is használható. A tulajdonosok engedtek kérésének, hiszen a mérnök minden eddigi konstrukciója sikert hozott a cégnek.

Az egészen különleges kialakítású, minden addigitól eltérő Tempo G (Geländewagen = terepjáró kocsi) 1200-as járművét 1936-ban mutatta be. A gépkocsi két meghajtóegységgel volt felszerelve. A gépkocsiban elöl is és hátul is egy-egy $600 \mathrm{~cm}^{3}$-es kéthengeres, kétütemű, vízhűtéses benzinmotor volt beszerelve, a velük egybeépített 4-fokozatú sebességváltóval. Teljesítményük együtt közel $40 \mathrm{LE}$ volt. A két motor mindegyike külön-külön és együtt is mü-

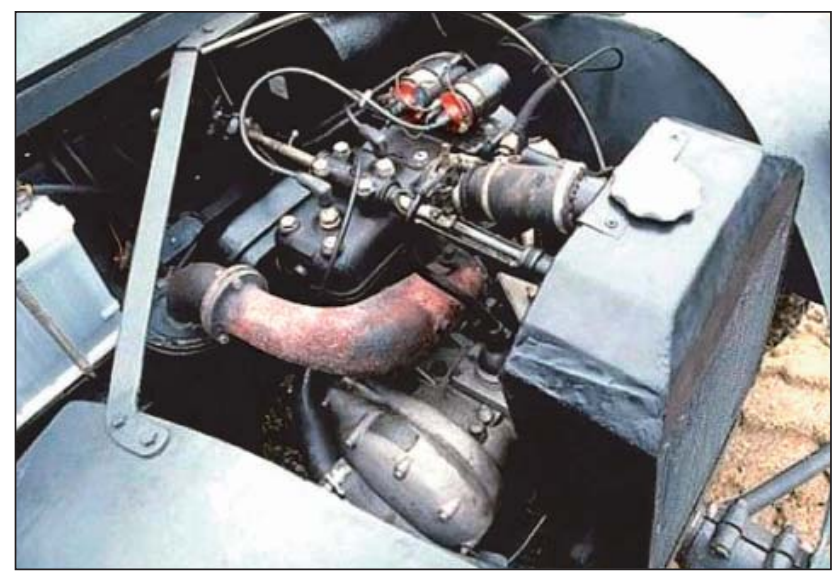

5. ábra. Az első motor. Megfigyelhetők a nagy hútő és a vastag hútő́folyadék-csövek. A hengerfejen rögzítve a sebességváltó rudazata, és annak csuklói is láthatóak

ködtethető volt, a szükségletnek megfelelően. A két motor egyidejű használata értelemszerűen összkerékhajtást jelentett, ami a nehéz terepszakaszokon is átsegítette a gépkocsit. A szokatlanul hosszú személygépkocsi fordulását megkönnyítendő - külön kapcsolhatóan - mind a négy kerék kormányozható is volt, nem egyedüliként a német terepjáró gépkocsik között. Az oldalt elhelyezett két pótkerék a tengelyén el tudott forogni, így például egy dombon sem ült fel a gépkocsi.

Mindezekkel a tulajdonságokkal számtalan, terepjáró gépkocsik részére kiirt nemzeti és nemzetközi versenyen vett részt, ahol mindig sikerrel szerepelt a Tempo G 1200-as.

\section{A GÉPKOCSI FELÉPITÉSE, RÉSZEGYSÉGE}

Mindkét motor a központi csővázhoz volt rögzítve, azonban lényegesen eltérő módon. A hátsó motor a szokásos felfüggesztéssel, az első a hossztartó középvonalában görgőscsapágyakon jobbra és balra kb. $25^{\circ}$-ban - a hűtővel és a sebességváltóval együtt - el tudott billenni. E megoldással a négy kerék szinte mindig megtartotta kapcsolatát a talajjal.

Ezek a kétütemű, kéthengeres, vízhűtéses motorok egymástól teljesen függetlenül külön-külön vagy egyszerre is működtethetők. Mindkét motor saját - ma a gépkocsiknál már alig alkalmazott - dinastarterrel volt felszerelve, ami indítómotor és dinamó is egyben. Ennek közepén volt a nálunk is ismert kétütemű kocsikkal azonos kialakítású

6. ábra. A terepjáró páncéltörő ágyút vontat

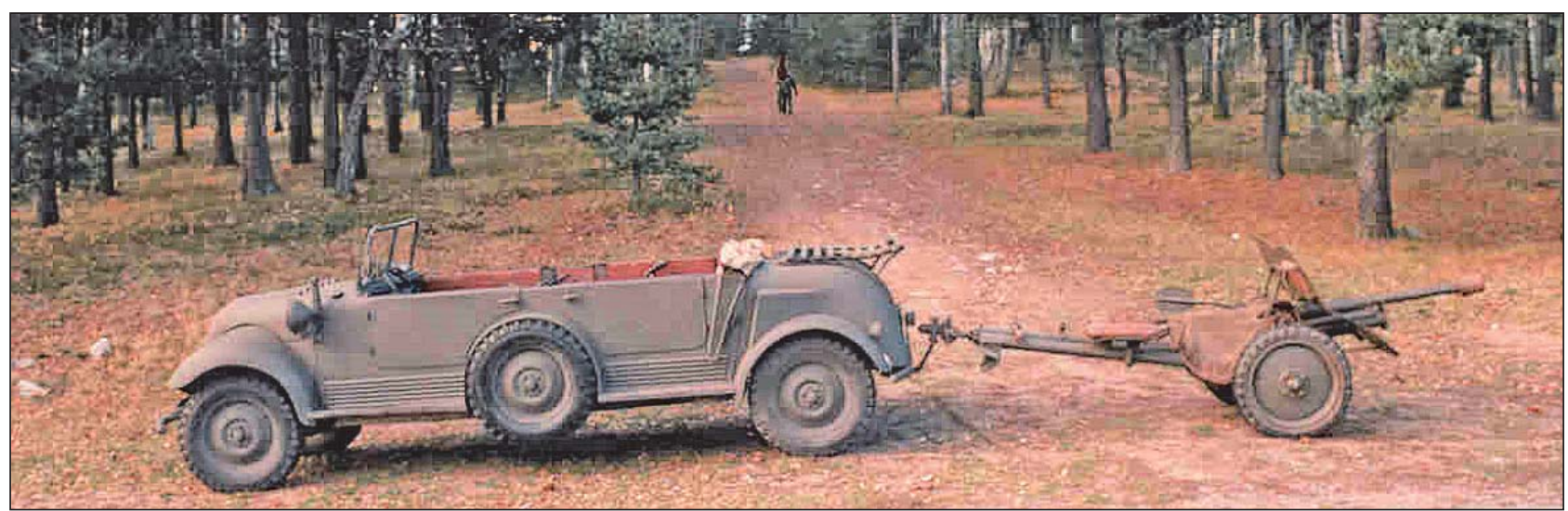


1. táblázat. A Tempo G 1200-as múszaki adatai

\begin{tabular}{|c|c|}
\hline Méretek (hosszúság/szélesség/magasság) & $4000 / 1600 / 1500 \mathrm{~mm}$ \\
\hline Tengelytávolság & $2830 \mathrm{~mm}$ \\
\hline Motor fajtája & ILO kétütemü-kéthengeres, vízhűtéses motor $(2 \times)$ \\
\hline Lökettérfogat - teljesítmény & 594 cm³ - 19 LE (×2) 3500 f/perc-nél \\
\hline Üzemanyagtartály 2 db & egy 25 és egy 30 literes \\
\hline Fogyasztása (100 km-en) & 9,2 liter (egy motor), 13 liter (két motor) \\
\hline Akkumulátor & $6 \mathrm{~V} 12 \mathrm{Ah}(\times 2)$ \\
\hline Sebességváltó & 4 előre, 1 hátra (2 sebességváltó) \\
\hline Meghajtás & 2 , vagy 4 kerék \\
\hline Kerékfelfüggesztés & elöl/hátul lengőkarok, egyenként 3 spirálrugóval \\
\hline Fék (láb/kézi) & dobfék, huzalműködtetéssel \\
\hline Kerekek & $5.00-17(4.75-17)$ \\
\hline Üres súly & $1150 \mathrm{~kg}$ \\
\hline Gázlómélység & $0,6 \mathrm{~m}$ \\
\hline Max. sebesség & 82 km/h (két motorral) \\
\hline
\end{tabular}

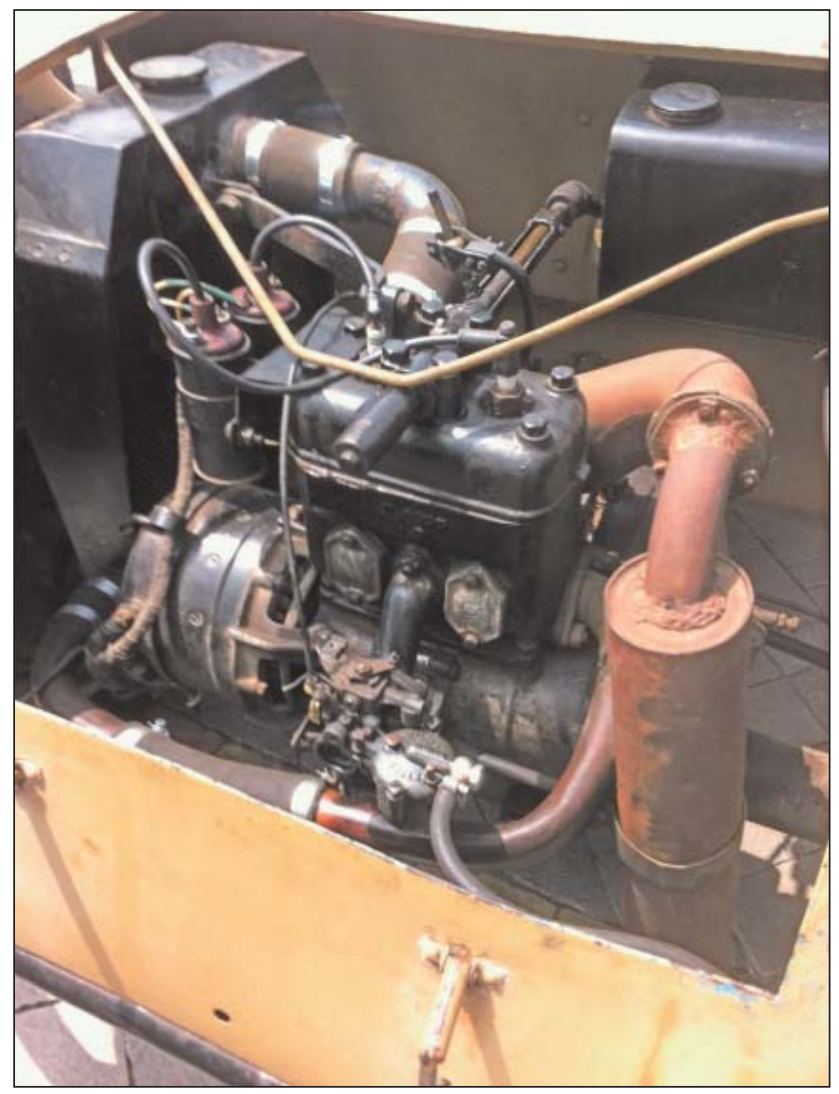

7. ábra. A hátsó motor. Balra a kopoltyúnyílás felé fordított hưtő, és az utastérből hátrafelé kilépő, ugyancsak

hengerfejre rögzített sebességváltó-rudazat a csuklókkal

gyújtás-alaplap, és a dinamó üzemhez egy Bosch „F” feszültségszabályzó.

A kétütemű, kéthengeres motorok a bejáratás ideje alatt 1:20-as (a francia nyelvű leírásban 1:15-ös), majd később 1:25-ös keverékkel üzemeltek.

A két motor közül a müszerfalon lévő választókapcsoló bal oldali állásával az első, jobb oldali állásával a hátsó motor volt indítható. A hagyományos helyen lévő gázpedál mindkét karburátort egyszerre szabályozta.
A motorok mellé szerelt üzemanyagtankok vezetékébe az ejtőtartályos megoldás miatt benzincsap volt iktatva, amit tartósabb állás esetén zárni kellett.

A „könnyen eltávolítható” kipufogódobokat minden $5000 \mathrm{~km}$ után le kellett szerelni és ki kellett tisztítani.

Amint a képeken látható, a hűtők és a hűtőfolyadékcsövek is lényegesen erősebbre méretezettek, mint ma szokásos, ami egyértelműen a hűtővíz szivattyú nélküli, termoszifonos hütésre utal.

Érdekes a két hűtőventilátor eltérő meghajtása. A hátsó (ott is a menetirányra keresztben álló) motornál a bal oldali szellőzőkopoltyú felé fordított hűtőn át levegőt beszívó ventilátor meghajtása közvetlenül a főtengelyről történt. Ez elöl csak egy szöghajtással volt megoldható, mert ez a fajta hűtőrendszer az elöl belépő menetszél hűtő hatásáról nem mondhatott le.

A két sebességváltót a nyári és téli üzemtől függően más-más viszkozitásúra kevert olajjal kellett feltölteni.

A kapcsolórúd szét- vagy összekapcsolásával - attól függően, hogy egy vagy két motor üzemelt - csak az egyik, vagy egyszerre mindkét sebességváltó működtethető volt. A sebességek kapcsolása a szokásostól eltérő, a kocsi hossztengelyéhez viszonyítva keresztirányú volt.

A kuplung többtárcsás, parafabetétes, olajfürdős kivitelű. A szokásos helyen lévő egyetlen kuplungpedál állandóan, egyszerre működtette mindkét kuplungot, egy motor üzeme esetén is. (A szerző ezúton szeretne köszönetet mondani feleségének Borikának, minden munkájához nyújtott önzetlenül odaadó, forráskutató, szövegformáló és különösképpen számítógépes segítségéért, mely nélkül egyetlen cikke sem készülhetett volna el.)

$$
\text { (Folytatjuk) }
$$

\section{FELHASZNÁLT FORRÁSOK}

Ulrich Menzel úr, Tempo-Club Deutschland szíves közlései;

http://www.tempo-dienst.de/Modelluebersicht/ tempostory.html;

v8cars.hu/cikk0357/otdk-2013-molnar-gyula.pdf;

Werner Oswald: Die Kraftfahrzeuge und Panzer. Motorbuch Verlag. 